Relations industrielles

Industrial Relations

\title{
Adams, Roy J., Industrial Relations Under Liberal Democracy
}

\section{John Godard}

Volume 50, numéro 4, 1995

L'ergonomie et les relations industrielles

Ergonomics and Industrial Relations

URI : https://id.erudit.org/iderudit/051062ar

DOI : https://doi.org/10.7202/051062ar

Aller au sommaire du numéro

Éditeur(s)

Département des relations industrielles de l'Université Laval

ISSN

0034-379X (imprimé)

1703-8138 (numérique)

Découvrir la revue

Citer ce compte rendu

Godard, J. (1995). Compte rendu de [Adams, Roy J., Industrial Relations Under Liberal Democracy]. Relations industrielles / Industrial Relations, 50(4), 893-895.

https://doi.org/10.7202/051062ar

Tous droits réservés @ C Département des relations industrielles de l'Université Laval, 1995
Ce document est protégé par la loi sur le droit d'auteur. L'utilisation des services d'Érudit (y compris la reproduction) est assujettie à sa politique d'utilisation que vous pouvez consulter en ligne.

https://apropos.erudit.org/fr/usagers/politique-dutilisation/ 
Si les droits nord-américains de la négociation collective, dont les droits canadiens et québécois, entretiennent depuis fort longtemps une conception intense de la négociation d'entreprise et du droit à celle-ci, le droit français impose, par ce droit général des salariés à la négociation collective, la "démocratie économique et sociale ", à côté de la démocratie politique dans le pays. Cette conception englobante de l'ordre social parait étrangère au droit canadien.

PIERRE VERGE

Université Laval

\section{Industrial Relations Under Liberal Democracy}

by Roy J. ADAMS, Columbia, S.C., University of South Carolina Press, 1995, 219 p., ISBN 1-57003-019-7.

This book has two purposes. The first is to delineate and explain the essential differences between the industrial relations (IR) systems of North America and those of other developed liberal democracies. The second is to draw lessons for the U.S. and Canada, based upon these differences and the performance outcomes associated with them.

The book begins with a short chapter on the early history of IR institutions, and of the "strategic choices" faced by labour movements at the end of the nineteenth century. This chapter is very sketchy and for the most part covers familiar ground, but it provides a nice set-up for the remainder of the book.

Chapters two and three address, respectively, the "European mainstream" and "North American exceptionalism," essentially documenting the different trajectories taken by the European and the North American IR systems from the late 1800 s to the present. In discussing the European mainstream, the author focuses upon Germany and Sweden, maintaining that the development of powerful socialist movements in these countries during the early 1900 s forced employers and states to forge historical compromises which recognized the right of centralized labour confederations to represent and bargain on behalf of all workers, while largely excluding unions from direct involvement in the management of work organizations. In contrast, the "socialist threat" was never as strong in North America, so neither employers nor the state found it necessary to forge a similar compromise. Instead, a more narrowly defined and decentralized system developed, in which workers formally enjoy the right to organize and bargain with their employers, but in which the legitimacy and influence of labour unions has been tenuous. In discussing these developments, Adams draws extensively upon the work of Selig Perlman and Adolf Sturmthal, but concludes that neither is entirely satisfactory in accounting for American exceptionalism.

Chapter four is perhaps the most valuable in the book, comparing the Canadian and U.S. systems with their European counterparts, while acknowledging differences between individual nations. This chapter provides an interesting and in some places a provocative analysis, identifying similarities and differences in the coverage, structure, scope, and processes of collective bargaining, as well as in strike laws and dispute resolution procedures.

Adams continues his comparative analysis in the following two chapters, with chapter five focusing upon differences in union densities and bargaining coverage, and chapter six focusing upon differences in socioeconomic performance. While acknowledging some positive attributes of the North American variant, he considers the North American system to be inferior in a number of areas, including bargaining coverage, 
strike levels, unemployment levels, participation, justice and dignity within the employment relation, employment security, and productivity growth rates.

In the final two chapters, Adams first provides greater details about, and for the most part extols the virtues of, the German, the Swedish, and the Japanese systems (chapter seven), and then offers his own theory of variation in IR systems and his prescriptions for the future (chapter eight). The "most fundamental proposition" in his theory is that differences "can be traced back to labor's choice of ideology" (p. 165), though he also recognizes that this choice can be highly constrained, arguing that a weak "left-radical movement" largely accounts for why North American employers and governments did not accommodate unions to the same extent as their European counterparts. Finally, his prescriptions are based upon the argument that the Canadian and U.S. economies have been characterized by inferior performance outcomes, and that this is largely attributable to higher levels of adversarialism, which in turn largely reflect various shortcomings of the U.S. and Canadian systems. His conclusion is thus that there is a need to "transcend" adversarialism by adopting a number of major reforms. These include: (1) legally requiring employers to recognize and bargain with "any employee appointed representative," (2) the establishment of statutory works councils, (3) annual, employer initiated, wage bargaining, (4) worker representation on corporate boards and on the boards of all agencies responsible for social and labour market issues, and (5) a public commitment by government to seek tripartite consensus on relevant issues.

Overall, this is a highly informative, easy to read, timely, and thought provoking book, one which provides an invaluable introduction for both scholars and advanced students interested in comparative IR systems, and which advances us beyond the often myopic and tire- some discourse about managerial "innovations" which has become so prevalent over the past decade. For these reasons, this book could well become a classic in the field. However, it is written from within the institutionalist tradition, and while it represents this tradition at its best, scholars from other traditions may have some problems with it.

First, though Adams draws upon a number of institutionalist theories of the labour movement, his analysis is not informed by any broader theoretical perspective or debate as to the nature and development of liberal democracies. Nor is it informed by any explicit theory of unions as organizations, of employers, or of the state. This would appear to be by design, as Adams has written broadly about theory elsewhere. But for the more theoretically minded, the result may be a certain conceptual fuzziness, and in particular a lack of theoretical specificity as to why the actors make the choices they do, and even which actors appear to be making which choices.

Second, while the author addresses the importance of political forces in initially shaping IR systems, some readers may take issue with his tendency, qua Dunlop, to analyze these systems and various outcomes associated with them in isolation from their broader institutional contexts. For example, there is a growing literature on the implications of different financial institutions and ownership structures for managerial decisions and economic performance in general. Such differences may have important implications both for national IR systems and for the outcomes Adams associates with these systems. Yet they are not considered in this book.

Third, the author's discussion of the advantages of alternative systems may pose problems for some readers. Particularly debatable are the virtues he extols for the Japanese system, where union density has now dropped to around 25 percent. In addition, in making his 
case against North American adversarialism, Adams makes much of the superior rates of productivity growth in Europe and Japan from 1960 to 1990. Yet there is no consistent pattern if one looks at his data for the 1980s (p. 136), even though, according to Adams, nonadversarial systems had major restructuring and hence performance advantages during this period. Moreover, based upon purchasing power comparisons, the U.S. still had the highest level of productivity per person employed of any liberal democracy as of 1992 , while Canada ranked anywhere from second to fourth in the world, depending upon the method of calculation employed. Thus, whether "nonadversarial" systems actually do give rise to superior economic performance is unclear.

These are, however, largely paradigmatic issues, and they are not in any way devastating to the book. Instead, they suggest only that this book should be read critically and supplemented with other sources if adopted for use in the class room. As an introduction to comparative IR from a North American perspective, this book is highly worthwhile, serving to provoke as well as inform. In particular, it cuts through the maze most North Americans typically face when attempting to study alternative IR systems. This is not an easy task, and the author as a result focuses primarily upon the differences between the noncorporatist systems of the U.S. and Canada, and the neocorporatist systems of Sweden and Germany. But, at minimum, this book provides an excellent foundation for subsequent, more in-depth study of comparative IR systems.

To conclude, Adams does a great job of analyzing the essential differences between North American and other liberal democratic IR systems, and, more important, of illustrating why these differences are of relevance to North Americans. As a result, this book should not only be of value in the class room, it should also help to stimulate greater interest in comparative IR in both academic and policy circles. The author has made an important contribution, and is to be congratulated.

JOHN GODARD

University of Manitoba

Relations professionnelles, emploi et formation au Québec

Critique Régionale, $\mathrm{n}^{\text {os }} 23-24,1994$, Université Libre de Bruxelles, 161 p., ISSN 0770-0075.

C'est comme lecteur européen, familier sans être expert de la réalité québécoise, que j'ai abordé cette publication. Dans son introduction en effet, les responsables - québécois - de cette livraison de Critique Régionale précisent que son but est "de fournir aux lecteurs européens une vision et de la réalité du monde du travail au Québec et des recherches qui s'y font ". On peut d'emblée souligner que le but est pour l'essentiel rempli. Celui qui ne connaît en rien le système de relations industrielles québécois, celui qui s'interroge sur les évolutions des grands paramètres de l'emploi ou souhaite saisir les grandes lignes des politiques menées à l'endroit de l'enseignement ou de la formation professionnelle y trouvera un panorama large et documenté. Si certains volets paraissent moins développés - on aurait souhaité une synthèse des travaux quantitatifs menés dans le domaine de l'insertion professionnelle des jeunes ou des sans-emploi -, si d'autres sont interrogés moins sur le plan factuel que celui des problèmes d'analyse qu'ils génèrent (l'évolution de l'organisation du travail), il n'en demeure pas moins que, globalement, le numéro alimente une réflexion intéressante et présente une vue d'ensemble sur le Québec en ces matières. 